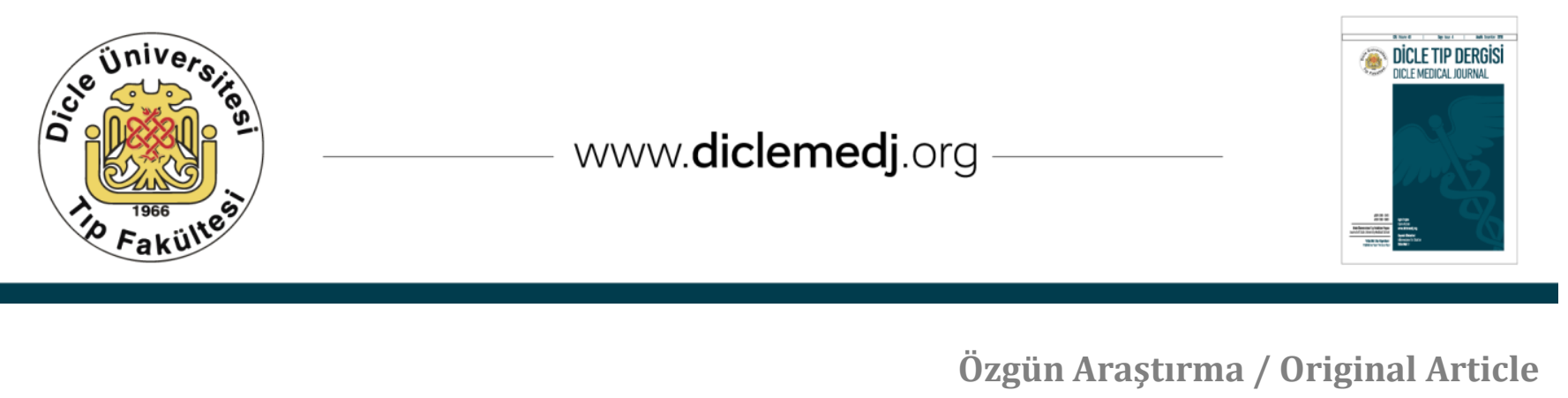

\title{
Cannulation of Innominate Artery during Proximal Aortic Aneurysm Repair
}

\author{
Ahmet Dolaoglu' ${ }^{1}$ Eyup Avci², Onursal Bugra ${ }^{3}$ \\ 1 Balıkesir Üniversitesi Tıp Fakültesi, Kalp ve Damar Cerrahisi AD, Balıkesir, Turkey, ORCID: 0000-0001-9161-2632 \\ 2 Balıkesir Üniversitesi Tıp Fakültesi, Kardiyoloji AD, Balıkesir, Turkey, ORCID: 0000-0002-7790-8450 \\ 3 Balıkesir Üniversitesi Tıp Fakültesi, Kalp ve Damar Cerrahisi AD, Balıkesir, ORCID: 0000-0002-4227-9420
}

\begin{abstract}
Objective: There are many debates for cannulation sites during aortic surgeries. The cannulation technique which is providing antegrade flow is associated with better survival and neurological outcomes than retrograde flow. For this purpose, innominate and axillary artery cannulation have been increasingly used for cardiopulmonary bypass recently. We aimed to present our experience with innominate artery cannulation for cardiopulmonary bypass and antegrade selective cerebral perfusion during proximal aortic aneurysm repair.
\end{abstract}

Methods: A total of eighteen patients with proximal aortic aneurysm underwent surgical repair were included into the study. Pre-operative patient's charecteristis, surgical details and postoperative outcomes were investigated.

Results: The mean age was $58.8 \pm 10.2$ and majority of the patients were male (72\%). Bicuspit leafletes was found in 9 patients (50\%). Two patients died in postoperative period. No stroke or new neurological deficit was seen after procedures.

Conclusions: This study is emphasize that cannulation of innominate artery can be used in safe and effective during aortic surgery.

Keywords: Innominate artery, aortic surgery, cardiopulmonary bypass, aortic aneurysm.

DOI: $10.5798 /$ dicletip.474696

Yazışma Adresi / Correspondence: Ahmet Dolapoglu, Balıkesir Üniversitesi Tıp Fakültesi, Kalp ve Damar Cerrahisi AD, Balıkesir, Turkey e-mail:ahmetdolapoglu@yahoo.com 


\section{Proximal Aort Cerrahisinde Innominate arter kanülasyonu}

\section{Öz}

Giriş: Aort cerrahisi uygulamalarında kardiyopulmoner bypass için arteryel kanülasyon bölgesi hala tartışma konusudur. Son yıllarda antegrade akım sağlayan kanülasyon tekniklerinin retrograde akım sağlayan bölgelere göre sağ kalım ve nörolojik sonuçlar açısından daha faydalı olduğunun gözlenmesi üzerine innominate arter ve axiller arter kullanımını artırmıştır. Bu çalışmada aort cerrahisinde innominate arter kanülasyonu üzerine olan tecrübelerimizi paylaşmayı amaçladık.

Yöntemler: Çalışmaya proximal aort cerrahisi nedeniyle cerrahi tamir yapılan 18 hasta dahil edilmiştir. Hastaların preoperatif , operatif özellikleri ve post-operatif sonuçlar değerlendirilmiştir.

Bulgular: Çalışmaya dahil edilen hastaların ortalama yaşları 58.8 \pm 10.2 iken hastaların çoğunluğunu erkekler oluşturmaktaydı (\%72). Eşlik eden bicuspit art kapak patolojisi 9 hastada bulundu (\%50). Postoperatif mortalite iki iken hiçbir hastada cerrahi sonrası inme veya nörolojik defisit gelişmemiştir.

Sonuçlar: Çalışma sonrasında aort cerrahisinde kardiyopulmoner bypass için innominate arter kullanımının güvenli ve etkili olduğunu savunmaktayız.

Anahtar Kelimeler: Innominate arter, aort cerrahisi, kardiyopulmoner bypass, aort anevrizması

\section{INTRODUCTION}

The cannulation technique has been changed in aortic surgery over the time ${ }^{1}$. Femoral, innominate and axillary arteries are the most common options for arterial cannulation in proximal aortic surgery including ascending and arch of aorta ${ }^{2}$. Recent studies have indicated that antegrade flow provides better neurological outcome and reduces the mortality on these complex procedures. For this purpose, preference of femoral artery which is providing retrograde flow have been decreased recently ${ }^{3}$. Another advantage of axillary and innominate artery cannulation is that antegrade cerebral perfusion can be performed during total circulatory arrest. Several studies have shown that excellent postoperative outcomes were obtained with using the innominate artery cannulation during aortic surgery ${ }^{4}$.

In this study we described our cannulation technique with innominate artery during proximal aortic surgery.

\section{METHODS}

Between January 2016 and July 2018, eighteen patients with ascending and/or arch of aortic aneurysm underwent open surgical repaire with innominate artery cannulation were included this study. Demographic characteristics, surgical detail and postoperative outcomes were obtained from the patients' charts.

The study complies with the Declaration of Helsinki and was approved by the ethics committee of the author's institute. Written Informed consent was obtained from all patients.

Before surgery, transthoracic echocardiography was performed in all patients for evaluation of the LVEF, end diastolic left ventricular diameter (LVEDD), aortic, mitral and tricuspit valves. Coronary anjiography was also performed in patients older than 40 years of age or under risk for coronary artery disease. Decision was made for surgical plan after CT angiogram.

All surgeries were performed under general anesthesia with standard median sternotomy. After heparin administration, innominate artery was cannullated with $8 \mathrm{~mm}$ dacrron 
tubular graft with end to side configuration (Figure 1). Cardiopulmonary bypass (CPB) was used in all operation with cross-clamped aorta under cardioplegic arrest and hypothermia.

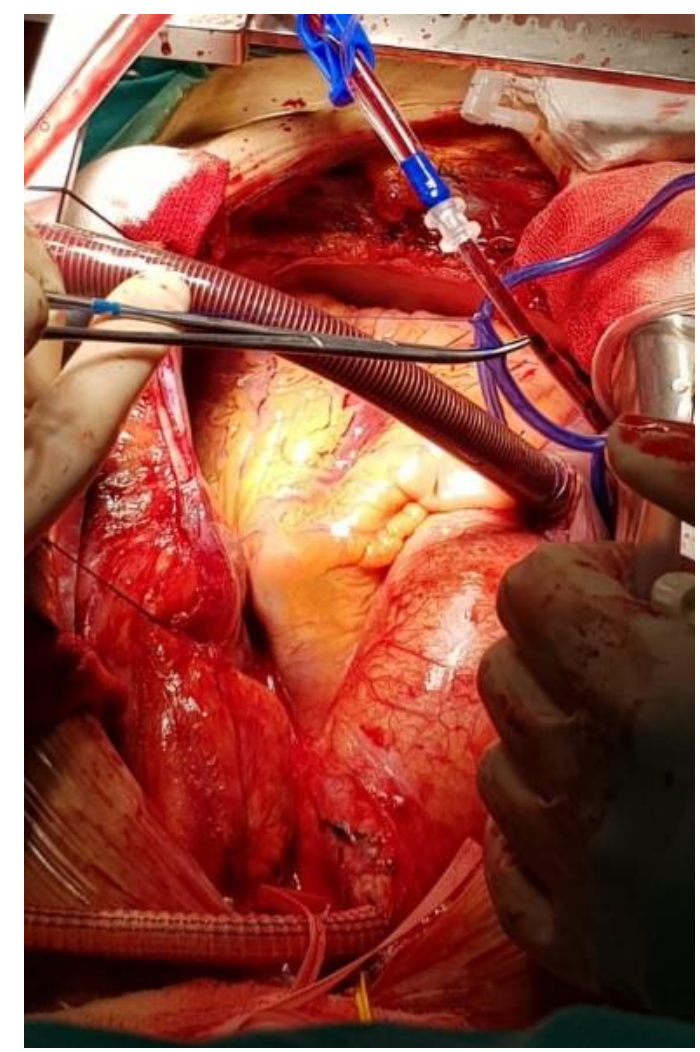

Figure 1: Innominate artery cannulation with $8 \mathrm{~mm}$ dacron graft

Multidose cold blood cardioplegia was administered intermittently in all patients through the aortic root in all the patients and retrogradely through the coronary sinus for myocardial protection.

CPB was initiated through the innominate arteial graft and innominate artery was then clamp and cerebral flow rate of 10-15 $\mathrm{ml} / \mathrm{kg} / \mathrm{min}$ was institute for the unilateral antegrade cerebral perfusion if systemic circulatory arrest necessary. After completing the circulatory arrest, the clamp was removed and after de-airing CPB was reinstituted in an antegrade fashion through the same artery. When complete the procedure,protamin was used for the neutrolization of the heparin and the graft was trimmed and sawn near the anostomosis.

The patient's demographic characteristics including age, gender, history of diabetes mellitus (DM), hypertension (HT), chronic kidney disease, cerebro-vascular accident, chronic pulmonary obstructive disease (COPD), coronary artery disease (CAD), left ventricular ejection fraction (LVEF), maximum aneurysm diameter and aortic valve pathology (severe aortic insufficiency, stenosis and bicuspit aorta); operative details including cardiopulmonary bypass (CPB) time and cross clamp (X-Clamp) time and total circulatory arrest time were collected.

Post-operative outcomes were recorded: mortality, renal failure which is requiring dialysis and neurologic deficits (stroke). Additionally post-operative length of stay and length of post-operative mechanical ventilation times were calculated.

\section{RESULTS}

Preoperative patient characteristics are listed in Table 1. A total of 18 patients were included in this study. The mean age was $58.8 \pm 10.2$ and majority of the patients were male $(72 \%)$. Ten patients (55\%) had hypertension and concomitant aortic valve pathology including severe aortic stenosis, insufficiency and bicuspit leafletes was found in 9 patients (50\%).

Operative details are presented in table 2. Various aortic procedures were performed according to the underlying pathology. A supra-coronary ascending aortic replacement in $8(44 \%)$ patients, and bental procedure in 5 patients $(27 \%), 4$ patients $(22 \%)$ underwent aortic valve replacement and supracoronary ascending aortic replacement, and 1 patient had total arch repair. Two pateients had concomitant coronary bypass grafting and 1 patient had mitral valve replacement with aortic prodecure. Mean CPB and X-Clamp times 
were $146.2 \pm 25$ and $84.6 \pm 15.7$ minutes respectively. Total circulatory arrest was performed in 7 patients during distal anostomosis.

Table 1: Demographic charecteristics

\begin{tabular}{lc}
\hline Demographic Variable & N(\%)/Mean \pm SD \\
\hline Age & $58.8 \pm 10.2$ \\
\hline Gender (Male) & $13(72 \%)$ \\
\hline HT & $10(55,5 \%)$ \\
\hline DM & $4(22 \%)$ \\
\hline CKD & $1(5 \%)$ \\
\hline COPD & $2(11 \%)$ \\
\hline CVA & 0 \\
\hline CAD & $2(11 \%)$ \\
\hline $\begin{array}{l}\text { Aortic Valve Pathologies } \\
\text { (AI-AS-Bicuspit Aorta) }\end{array}$ & $9(50 \%)$ \\
\hline LVEF & $54.1 \pm 6.1$ \\
\hline $\begin{array}{l}\text { Maximum Ascending Aortic Diameter } \\
\text { (mm) }\end{array}$ & $58.5 \pm 8.1$ \\
\hline
\end{tabular}

Abbrevetion:

HT: HipertensioC, DM: Diabetes Mellitus, CKD: Chronic Kidney Disease

CVA: Cerebro vascular accident, COPD: Chronic obstructive pulmonary disease

CAD: Coronary artery disease, AI: Aortic, insuffuciency AS:

Aortic stenosus

LVEF: Left ventricular ejection fraction

Clinical outcomes are summarized in Table 2 . Two patients were death in post-operative early period due to multiple organ failure. Two patients had acute renal injury which is requiring dyalisis after surgery. No stroke or new neurologic deficit was seen in postoperative period.

Additionally mean mechanical ventilation time was $14.3 \pm 19.2$ hours and lenght of hospital stay was $7.5 \pm 2.1$ days.

\section{DISCUSSION}

Reconstruction of the proximal aortic aneurysm is associated with higher mortality and morbidity rate ${ }^{5}$. Neurological complication is common with this procedure. Recent studies have shown that antegrade flow provides more effective brain protection during $\mathrm{CPB}^{6}$. Over the past two decades, while femoral artery canulation has been decreased in use, axillary and innominate artery cannulation is progressively increse due to providing antegrade flow characteristics. Axillary and innominate artery are also facilitates the antegrade cerebral perfusion in the case of total circulatory arrest ${ }^{7}$. Compare with the axillary artery, innominate artery is easily accessible through median sternotomy and does not need an additional incision, which may be complicated by local infections, brachial plexus injuries or vascular injuries ${ }^{8}$. It is always easy and fast to prepare the innominate artery even in obese patients. Furthermore, the innominate artery has lower flow resistance than axillary artery, and it facilitates to achieve full CPB flow more easily.

Table 2: Operative details and Postoperative Outcome

\begin{tabular}{lc}
\hline $\begin{array}{l}\text { Operative Detail } \\
\text { Post-operative Outcome }\end{array}$ & N(\%)/Mean \pm SD \\
\hline Bentall Op & $5(27 \%)$ \\
\hline $\begin{array}{l}\text { AVR+Supra Coronary Ascending Aortic } \\
\text { Replacement }\end{array}$ & $4(22 \%)$ \\
\hline $\begin{array}{l}\text { Supra Coronary Ascending Aortic } \\
\text { Replacement }\end{array}$ & $8(44 \%)$ \\
\hline Ascending Aortic and Total Arch Repair & $1(5 \%)$ \\
\hline Total Circulatory Arrest (Open Clamp) & $7(38 \%)$ \\
\hline Concomitant CABG & $2(11 \%)$ \\
\hline Concomitant MVR & $1(5 \%)$ \\
\hline CPB Time (minute) & $146.2 \pm 25$ \\
\hline X-Clamp Time (minute) & $84.6 \pm 15.7$ \\
\hline TCA Time (minute) & $28.7 \pm 10.6$ \\
\hline Mortality & $2(11 \%)$ \\
\hline ARF & $2(11 \%)$ \\
\hline New stroke or CVA & 0 \\
\hline Mechanical Ventilation Time (hour) & $14.3 \pm 19.2$ \\
\hline Lenght of Hospital stay (day) & $7.5 \pm 2.1$ \\
\hline CPB: Cardiyopulmoner bypass, AVR: Aortic valve replacement \\
\hline grafting, ARF: Acute renal failure
\end{tabular}


In our study we have cannulated innominate artery without any complication such as bleeding, dissection and hematoma. Compare with previously reported studies by others ${ }^{9,10}$, in our experience, cannulation of the innominate artery was associated with similar hospital outcomes. Hospital mortality was $11 \%$, and renal failure was $11 \%$. These outcome rate was slightly higher than previously reported studies and we think that the reason may be our small patient population. On the other hand, we don't have any neurological complication in our patients postoperatively.

In conclusion, the innominate artery represents a valuable site for arterial cannulation, during repair of the proximal aortic aneurysm. This cannulation site allows surgeon to prevent time waste for incision another site and also providing more effective brain protection. it allowed complex aortic interventions to be performed with excellent results in terms of mortality and neurological outcomes.

Declaration of Conflicting Interests: The authors declare that they have no conflict of interest.

Financial Disclosure: No financial support was received.

\section{REFERENCES}

1. Ren Z, Wang Z, Hu R, et al. Which cannulation (axillary cannulation or femoral cannulation) is better for acute type A aortic dissection repair? A meta-analysis of clinical studies. Eur J Cardiothorac Surg. 2015; 47: 408-15.

2. Patris V, Toufektzian L, Field M, et al. Is axillary superior to femoral artery cannulation for acute type A aortic dissection surgery? Interact Cardiovasc Thorac Surg. 2015; 21: 515-20.

3. Wong DR, Coselli JS, Palmero L, et al. Axillary artery cannulation in surgery for acute or subacute ascending aortic dissections. Ann Thorac Surg. 2010; 90: 731-7.

4. Uchino G, Yunoki K, Sakoda N, et al. Innominate artery cannulation for arterial perfusion during aortic arch surgery. J Card Surg. 2017; 32: 110-3.

5. Martino A, Re FD, Blasi S, et al. Surgical treatment of annuloaortic ectasia-replace or repair ? Aorta (Stamford). 2017; 5: 139-47.

6. Preventza 0, Garcia A, Tuluca A, et al. Innominate artery cannulation for proximal aortic surgery: outcomes and neurological events in 263 patients. Eur J Cardiothorac Surg. 2015; 48: 937-42.

7. Kaul P. How I do it-sole innominate cannulation for acute type A aortic dissection. J Cardiothorac Surg. 2012; 7: 125.

8. Murakami T, Hosono M, Shibata T. Tips and avoid complications related to direct cannulation of the axillary artery. Asian Cardiovasc Thorac Ann. 2018; 26: 250-1.

9. Hu Z, Wang Z, Ren Z, et al. Similar cerebral protective effectiveness of antegrade and retrograde cerebral perfusion combined with deep hypothermia circulatory arrest in aortic arch surgery:a metaanalyzis and systemic review of 5060 patients. J Thorac Cardiovasc Surg. 2014; 148: 544-60.

10. Foley LS, Yamanaka K, Reece TB. Arterial cannulation and cerebral perfusion strategies for aortic arch operations. Semin Cardiothorac Vasc Anesth. 2016; 20: 298-302. 